\title{
Effect of dietary supplementation of sea buckthorn and giloe leaf meal on the body weight gain, feed conversion ratio, biochemical attributes, and meat composition of turkey poults
}

\author{
Aditya Sharma ${ }^{1}$, Pankaj Kumar Shukla ${ }^{1}$, Amitav Bhattacharyya ${ }^{1}$, Upendra Kumar ${ }^{1}$, Debashis Roy ${ }^{2}$, Brijesh Yadav ${ }^{3}$ and \\ Atul Prakash ${ }^{4}$
}

\begin{abstract}
1. Department of Poultry Science, College of Veterinary Science and Animal Husbandry, Mathura - 281001 , Uttar Pradesh, India; 2. Department of Animal Nutrition, College of Veterinary Science and Animal Husbandry, Mathura - 281 001, Uttar Pradesh, India; 3. Department of Veterinary Physiology, College of Veterinary Science and Animal Husbandry, Mathura - 281 001, Uttar Pradesh, India; 4. Department of Pharmacology and Toxicology, College of Veterinary Science and Animal Husbandry, Mathura - 281001 , Uttar Pradesh, India.

Corresponding author: Amitav Bhattacharyya, e-mail: amitav16@rediffmail.com

Co-authors: AS: adityasharmagahar@gmail.com, PKS: pksmathura@yahoo.co.in, UK: drupendra85@rediffmail.com, DR: debashis2k4@gmail.com,BY: drbrijvet@gmail.com, AP: dratul2510@rediffmail.com

Received: 31-08-2017, Accepted: 21-12-2017, Published online: 31-01-2018
\end{abstract}

doi: 10.14202/vetworld.2018.93-98 How to cite this article: Sharma A, Shukla PK, Bhattacharyya A, Kumar U, Roy D, Yadav B, Prakash A (2018) Effect of dietary supplementation of sea buckthorn and giloe leaf meal on the body weight gain, feed conversion ratio, biochemical attributes and meat composition of turkey poults, Veterinary World, 11(1): 93-98.

\begin{abstract}
Aim: In the recent past, few studies have been carried out about sea buckthorn (SBT) and giloe in chicken as a part of the quest for suitable alternatives to antibiotics. However, studies in turkeys are lacking. Hence, the present study was conducted to evaluate the effects of SBT and giloe leaf meal by dietary feed supplementation in turkey poults.

Materials and Methods: A total of 1-day-old turkey poults $(n=84)$ of small white variety were distributed into four dietary treatments having three replicates each with seven birds. The study was conducted in turkey poults during 0-8 weeks of age. During the experiment, the poults were fed basal ration (28\% crude protein [CP], $2800 \mathrm{Kcal} / \mathrm{kg} \mathrm{ME}) \mathrm{T} 1$, T2-basal ration was supplemented with SBT leaf meal powder at $0.5 \%$, T3-basal ration was supplemented with giloe leaf meal powder at $0.5 \%$, and T4-basal ration was fed along with supplementation of both SBT at $0.5 \%$ and giloe leaf meal powder at $0.5 \%$.

Results: T2 turkey poults had a significantly higher $(\mathrm{p}<0.01)$ body weight gain than T3 and T4 at $7^{\text {th }}$ week of age. Weekly body weight gain was significantly higher $(\mathrm{p}<0.05)$ in T2 than T3 during $5^{\text {th }}-8^{\text {th }}$ week and $0-8^{\text {th }}$ week of the growth phase. Feed conversion ratio $(F C R)$ was significantly better $(\mathrm{p}<0.01)$ in T2 than other treatment groups during $4^{\text {th }}-8^{\text {th }}$ week phase of growth (2.09 vs. 2.36, 2.29 and 2.31). Further, FCR was significantly better $(\mathrm{p}<0.01)$ in T2 group as compared to other treatment groups during $0-8^{\text {th }}$ week of growth phase (1.95 vs. 2.21, 2.21 and 2.12). Plasma uric acid was found significantly increased $(\mathrm{p}<0.05)$ in T1 than T3 and T4, and alkaline phosphatase value was significantly higher $(\mathrm{p}<0.05)$ in T1 and T3 than T2. Zinc content of breast (pectoralis major) muscles was significantly higher $(\mathrm{p}<0.05)$ in T2 and T4 as compared to T1, while ether extract (EE) in thigh (ilio tibialis) muscles was significantly higher $(\mathrm{p}<0.05)$ in T2 as compared to the other treatment groups.
\end{abstract}

Conclusion: It may be concluded that supplementation of SBT leaf meal at $0.5 \%$ may improve production performance of turkey poults. Supplementation of $0.5 \%$ SBT leaf meal may result in higher levels of zinc and EE in the breast and thigh cuts of turkey poults.

Keywords: giloe, growth, meat composition, sea buckthorn, turkey.

\section{Introduction}

One of the most promising approaches for a viable alternative to antibiotics has been the exploration of the power of nature, i.e. herbs, shrubs, and trees. It involves the medicinal use of plants and their extracts as supplements for eliciting production in poultry. In fact, the properties of plants and their extract have been exploited as preservatives, flavors, digestive enhancers, and remedies from ancient time in humans and animals.

Copyright: Sharma, et al. Open Access. This article is distributed under the terms of the Creative Commons Attribution 4.0 International License (http://creativecommons.org/licenses/ by/4.0/), which permits unrestricted use, distribution, and reproduction in any medium, provided you give appropriate credit to the original author(s) and the source, provide a link to the Creative Commons license, and indicate if changes were made. The Creative Commons Public Domain Dedication waiver (http:// creativecommons.org/publicdomain/zero/1.0/) applies to the data made available in this article, unless otherwise stated.
Sea buckthorn (Hippophae rhamnoides) (SBT) is a naturally growing shrub that is native to Eastern Europe and Asia and is found in the abundance in the Indian subcontinent, especially the North Western Himalayan regions [1]. SBT leaves contain significant amounts of proteins (11-20\%), amino acids $(0.73 \%$ lysine, $0.13 \%$ methionine, and cystine), minerals, folic acid, catechins, esterified sterols, triterpenols, and isoprenols [2-5]. Tannins hippophaenins A and B have been isolated from SBT leaf [6]. Tinospora cordifolia (giloe) is a deciduous climbing shrub found throughout tropical Asia. Leaves of the giloe are rich in protein $(11.2 \%)$ and are fairly rich in calcium and phosphorus [7-10]. Few studies have been under-taken on the effect of supplementation of SBT leaf meal and giloe on the growth performance in broilers, and it was found that SBTleaf meal and giloe 
may be a viable proposition for improving the growth and feed conversion ratio (FCR) in broilers [2,11-15]. However, studies in turkeys are lacking.

In view of above, the present study was designed to assess the effect of dietary supplementation of SBT and giloe leaf meal alone or in combination on the body weight gain, FCR, biochemical attributes, and meat composition of turkey poults.

\section{Materials and Methods}

\section{Ethical approval}

Experiments were carried out in accordance with the guidelines laid down by the Institute Animal Ethics Committee for the use of poultry birds.

\section{Preparation of SBT and giloe leaf meal}

Raw SBT leaves were procured from District Lahaul-Spiti in Himachal Pradesh, and T. cordifolia leaves were procured from Gahar village of District Bilaspur in Himachal Pradesh, India. Fresh leaves were ground and sun-dried in a clean and dust free environment to obtain a fine powder. The powder formed was packed in an airtight container.

\section{Experimental design, housing, feeding, and management}

Eighty-four straight run day old turkey poults were divided into four treatment groups comprising of three replicates and seven turkey poults in each replicate. The poults were wing banded, weighed individually, and distributed randomly on uniform body weight basis in the treatment groups. The poults were housed in deep litter under continuous lighting schedule with a floor space of $1.5 \mathrm{ft}^{2} /$ poult till 8 weeks of age. Water was offered ad libitum. There were four dietary treatments: T1 - basal or control diet (turkey starter ration; NRC, 1994), T2 - basal or control diet (T1) + supplementation of $0.5 \%$ SBT leaf meal, T3 - basal or control diet (T1) + supplementation of $0.5 \%$ giloe leaf meal, and $\mathrm{T} 4$ - basal or control diet (T1) + supplementation of $0.5 \%$ SBT leaf meal and $0.5 \%$ giloe leaf meal. Representative samples of SBT and giloe leaf meal and turkey feed were analyzed for their nutrient composition, namely, dry matter (DM), $\mathrm{CP}$, total ash, and crude fiber [16].

\section{Body weight gain and FCR}

Weekly body weight, group feed consumption, and mortality were recorded. FCR (feed intake: Body weight gain) of 0 to 8 weeks was calculated at the end of the experiment.

\section{Blood biochemical attributes}

Blood was collected from six turkey poults of each group at the end of the biological experiment from the wing vein with the help of heparinized and non-heparinized syringes and poured into sterile tubes. The blood samples were centrifuged for the $10-15 \mathrm{~min}$ at $2500 \mathrm{rpm}$. Plasma and serum were separated and stored in the refrigerator $\left(-20^{\circ} \mathrm{C}\right)$ until analyzed. Plasma cholesterol, high-density lipoprotein (HDL) cholesterol, protein, uric acid, glutamate oxaloacetate transaminase (GOT), glutamate pyruvate transaminase (GPT), and alkaline phosphatase (ALP) were determined using commercial kits of Span Cogent Diagnostics Product, India, according to the manufacturer's instructions. The lipid peroxidation (LPO)/malondialdehyde assay was done by the thiobarbituric acid reactive substance method [17]. Serum superoxide dismutase (SOD) activity was measured using the method as described by Madesh and Balasubramanian [18] with some modifications. In the microtiter plate method, the assay mixture in a total volume of $300 \mu 1$ per well consisted of $120 \mu 1$ phosphate buffer saline (PBS), $10 \mu 1$ serum sample, $5 \mu 1$ of $1.25 \mathrm{mM}$ 3-(4,5-dimethyl-2-thiazolyl)-2,5-diphenyl-2H tetrazolium bromide (MTT), and $15 \mu 1$ of freshly prepared $1 \mathrm{mM}$ pyrogallol solution to be added at the end. Sample was replaced with PBS in the blank. After an incubation period of $15 \mathrm{~min}, 150 \mu \mathrm{l}$ dimethyl sulfoxide was added and absorbance was taken in ELISA reader at $570 \mathrm{~nm}$. The percent inhibition by the presence of SOD was calculated from the reduction of the MTT color formation as compared to the MTT formazan formed in the absence of SOD which was taken as $100 \%$.

Proximate composition of breast (pectoralis major) and thigh (ilio tibialis) muscle of turkey poults

After 8 weeks of age, 6 birds from each treatment group ( 3 male and 3 female) were sacrificed, and thereafter, fresh samples of breast (pectoralis major) and thigh (ilio tibialis) muscles were processed and analyzed for DM, CP, ether extract (EE), total ash, calcium, and phosphorus [16]. Ca and $\mathrm{Zn}$ in breast and thigh were determined by atomic absorption spectroscopy (AAS). Samples were digested [19]. $1 \mathrm{~g}$ of the sample was taken. $1 \mathrm{ml}$ of pure nitric acid was added in $50 \mathrm{ml}$ digestion tube. Sample was kept overnight at room temperature. Digestion was done slowly at low heat $\left(<90^{\circ} \mathrm{C}\right)$ on micro digestion bench so that volume is reduced to about $0.5 \mathrm{ml}$. Double acid mixture ( $\mathrm{HNO} 3$ and $70 \% \mathrm{HClO} 4$, $3: 1)$ was added to make the volume $5 \mathrm{ml}$. Repeated digestion was done, till white fumes emanated from it. Digested final volume was about $0.5 \mathrm{ml}$. Triple glass-distilled water was added to make $10 \mathrm{ml}$. The concentration of calcium and zinc was measured in AAS-400 using the formula:

$\mathrm{Ca}$ or $\mathrm{Zn} \mathrm{mg/100} \mathrm{g}=\{$ Concentration of calcium or zinc in PPM or $\mathrm{mg} / \mathrm{l} \times$ volume made $\} /$ weight of sample.

\section{Statistical analysis}

Data were subjected to one-way analysis of variance in a completely randomized design [20] using the Statistical Package for the Social Sciences [21]. Homogenous subsets were separated using Duncan's multiple range test described by Duncan [22]. Differences among treatments were considered to be statistically significant when $p \leq 0.05$. 


\section{Results}

\section{Chemical composition of experimental diet}

The proximate principles, i.e., DM, total ash, EE, calcium, phosphorous, protein, crude fiber, zinc content of turkey starter feed, SBL meal, and giloe leaf meal have been summarized in Table-1.

\section{Average body weight gain}

Weekly body weight gain was found to increase till $8^{\text {th }}$ week (Table-2). T2 turkey poults had a significantly higher $(p<0.01)$ body weight gain than T3 and T4 at $7^{\text {th }}$ week of age. Further, T2 poults had a numerically higher body weight gain compared to the other treatment groups throughout the experiment. In addition, weekly body weight gain was significantly better $(\mathrm{p}<0.05)$ in T2 than T3 during 5-8 weeks and $0-8$ weeks of the growth phase (Table-3).

FCR

FCR was found comparatively better in T2 than other treatment groups during $0-4^{\text {th }}$ week phase of growth (Table-4). Thereafter, FCR was significantly better $(p<0.01)$ in T2 than other treatment groups during $4^{\text {th }}-8^{\text {th }}$ week phase of growth. Further, FCR was significantly better $(\mathrm{p}<0.01)$ in T2 group as compared to other treatment groups in $0-8^{\text {th }}$ week of growth phase.

\section{Blood biochemical parameters}

Effect of SBT and giloe leaf meal feeding on total plasma protein, total plasma cholesterol, plasma uric acid, plasma GOT, GPT, and ALP was determined (Table-5). HDL, SOD (superoxide dismutase), and LPO also determined (Table-6). There was no significant difference among the treatment groups in any of the blood biochemical indices except plasma uric acid and ALP. Plasma uric acid was significantly increased $(p<0.05)$ in control group than giloe and group having supplementation of both SBT and giloe leaf meal. Further, plasma ALP value was significantly higher $(\mathrm{p}<0.05)$ in control than SBT supplemented group.
Proximate analysis of breast (pectoralis major) muscles and thigh (ilio tibialis) muscles

No significant difference was observed in the proximate analysis of breast (pectoralis major) muscles of turkey poults, except zinc percent, which was significantly higher $(\mathrm{p}<0.05)$ in SBT and both SBT and giloe supplemented groups as compared to control at 8 weeks of age (Figure-1a-c). Similarly, no significant difference was observed in the proximate analysis of thigh (ilio tibialis) muscles of turkey poults, except in percent EE, which was significantly higher $(p<0.05)$ in SBT leaf meal supplemented group as compared to the other treatment groups (Figure-2a-c).

\section{Discussion}

\section{Chemical composition of experimental diet}

The proximate values of SBT leaf were in order as reported by Kashif and Ullah [5]. The proximate values of giloe leaf were in the same ranges as reported in other studies [7-10].

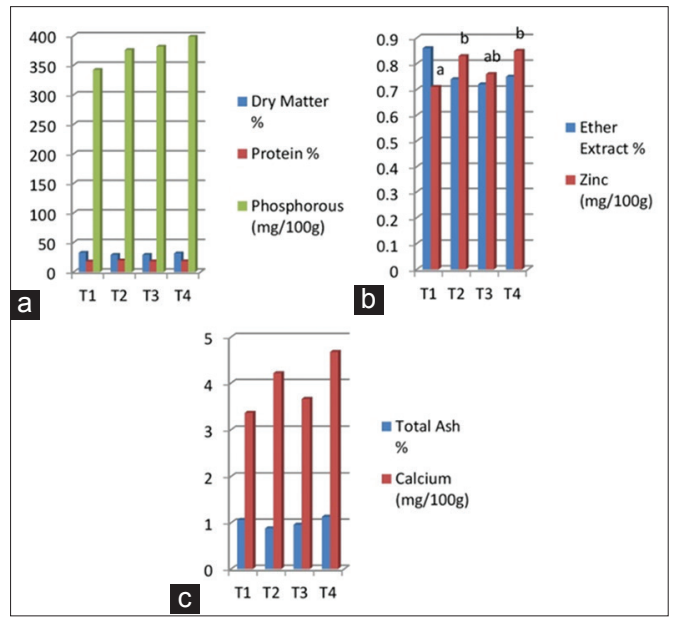

Figure-1: (a-c) Effect of sea buckthorn and giloe leaf meal supplementation on the proximate analysis of breast (pectoralis major) muscle of turkey poults after 8 weeks of age. Columns in the graph bearing different superscripts differ significantly $(p<0.05)$.

Table-1: Proximate analysis of turkey feed, sea buckthorn leaf, and giloe leaf.

\begin{tabular}{|c|c|c|c|c|c|c|c|c|}
\hline Category & $\begin{array}{c}\text { Dry matter } \\
(\%)\end{array}$ & $\begin{array}{c}\text { Total ash } \\
(\%)\end{array}$ & $\begin{array}{c}\text { Ether extract } \\
(\%)\end{array}$ & $\begin{array}{c}\text { Calcium } \\
(\%)\end{array}$ & $\begin{array}{c}\text { Phosphorous } \\
(\%)\end{array}$ & $\begin{array}{c}\text { Protein } \\
(\%)\end{array}$ & $\begin{array}{l}\text { Crude } \\
\text { fiber }\end{array}$ & $\begin{array}{l}\text { Zinc } \\
(\%)\end{array}$ \\
\hline Turkey feed & 89.29 & 8.93 & 2.57 & 2.03 & 1.33 & 27.7 & 21.2 & 0.0025 \\
\hline $\begin{array}{l}\text { Sea buckthorn } \\
\text { leaf meal }\end{array}$ & 41.4 & 8.19 & 6.93 & 1.56 & 1.14 & 12.26 & 18.48 & 0.0028 \\
\hline Giloe leaf meal & 52 & 11.2 & 1.79 & 0.28 & 0.58 & 13.87 & 21.54 & 0.0014 \\
\hline
\end{tabular}

Table-2: Effect of sea buckthorn and giloe leaf meal supplementation on the average weekly body weight gain ( $\mathrm{g}$ ) of turkey poults during 0-8 weeks of age.

\begin{tabular}{lcccccccc}
\hline Treatment & $\mathbf{1}^{\text {st }} \mathbf{w e e k}$ & $\mathbf{2}^{\text {nd }} \mathbf{w e e k}$ & $\mathbf{3}^{\text {rd }}$ week & $\mathbf{4}^{\text {th }}$ week & $\mathbf{5}^{\text {th }}$ week & $\mathbf{6}^{\text {th }}$ week & $\mathbf{7}^{\text {th }}$ week & $\mathbf{8}^{\text {th }} \mathbf{w e e k}$ \\
\hline T1 & 22.10 & 55.37 & 74.13 & 90.33 & 117.06 & 141.00 & $178.43^{\text {ab }}$ & 188.20 \\
T2 & 32.11 & 61.72 & 75.00 & 99.94 & 114.44 & 154.83 & $196.17^{b}$ & 211.94 \\
T3 & 23.44 & 52.29 & 66.33 & 82.14 & 97.41 & 126.67 & $159.16^{\mathrm{a}}$ & 185.11 \\
T4 & 31.77 & 54.43 & 72.87 & 95.00 & 113.47 & 124.50 & $161.20^{\mathrm{a}}$ & 202.17 \\
Pooled SEM & 1.86 & 1.90 & 1.97 & 2.84 & 6.17 & 5.21 & 5.19 & 6.65 \\
Sig level & NS & NS & NS & NS & NS & NS & p $<0.01$ & NS \\
\hline
\end{tabular}

Means bearing different superscripts within a column differ significantly $(p<0.05)$. NS=Not significant $(p>0.05)$, $\mathrm{SEM}=$ Standard error of means 


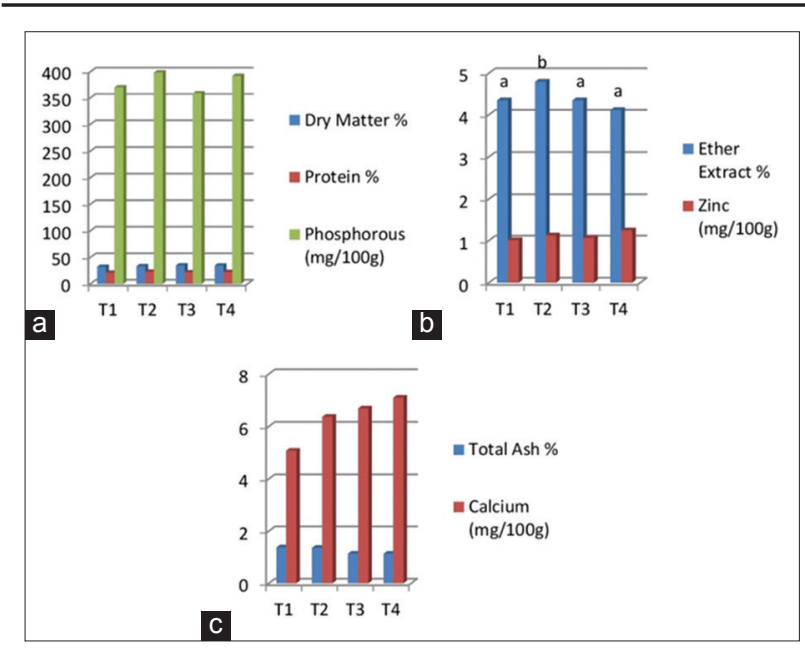

Figure-2: (a-c) Effect of sea buckthorn and giloe leaf meal supplementation on proximate analysis of thigh (ilio tibialis) muscle of turkey poults after 8 weeks of age. Columns in the graph bearing different superscripts differ significantly $(p<0.05)$.

Table-3: Effect of sea buckthorn and giloe leaf meal supplementation on weekly body weight gain $(\mathrm{g})$ of turkey poults at different phases of growth during 0-8 weeks of age.

\begin{tabular}{lccc}
\hline Treatment & $\mathbf{0 - 4}$ weeks & $\mathbf{4 - 8}$ weeks & $\mathbf{0 - 8}$ weeks \\
\hline T1 & 241.93 & $624.70^{\mathrm{ab}}$ & $866.63^{\mathrm{ab}}$ \\
T2 & 268.78 & $677.39^{\mathrm{b}}$ & $946.17^{\mathrm{b}}$ \\
T3 & 224.21 & $568.34^{\mathrm{a}}$ & $792.56^{\mathrm{a}}$ \\
T4 & 254.07 & $601.33^{\mathrm{a}}$ & $855.40^{\mathrm{ab}}$ \\
Pooled SEM & 7.67 & 15.18 & 21.30 \\
Significant level & $\mathrm{NS}$ & $\mathrm{p}<0.05$ & $\mathrm{p}<0.05$ \\
\hline
\end{tabular}

Means bearing different superscripts within a column differ significantly $(p<0.05)$. NS=Not significant $(p>0.05)$, $\mathrm{SEM}=$ Standard error of means

Table-4: Effect of sea buckthorn and giloe leaf meal supplementation on feed conversion ratio of turkey poults at different phases of growth during 0-8 weeks of age.

\begin{tabular}{lccc}
\hline Treatment & $\mathbf{0 - 4}$ weeks & $\mathbf{5 - 8}$ weeks & $\mathbf{0 - 8}$ weeks \\
\hline T1 & 2.06 & $2.36^{\mathrm{b}}$ & $2.21^{\mathrm{b}}$ \\
T2 & 1.80 & $2.09^{\mathrm{a}}$ & $1.95^{\mathrm{a}}$ \\
T3 & 2.14 & $2.29^{\mathrm{b}}$ & $2.21^{\mathrm{b}}$ \\
T4 & 1.94 & $2.31^{\mathrm{b}}$ & $2.12^{\mathrm{b}}$ \\
Pooled SEM & 0.05 & 0.03 & 0.04 \\
Sig level & $\mathrm{NS}$ & $\mathrm{p}<0.01$ & $\mathrm{p}<0.01$ \\
\hline
\end{tabular}

Means bearing different superscripts within a column differ significantly $(p<0.05)$. NS=Non-significant $(p>0.05)$, $\mathrm{SEM}=$ Standard error of means

\section{Average body weight gain}

It has been reported that SBT leaves contain significant amounts of proteins (11-20.7\%), amino acids ( $0.73 \%$ lysine, $0.13 \%$ methionine, and cystine) minerals, folic acid, catechins, esterified sterols, triterpenols and isoprenols [2-5]. In our study too, the sea buckthorn leaves contained $12.26 \%$ crude protein. This might have contributed in the higher body weight gain in the SBT leaf meal supplemented group in turkey poults. Further, our results collaborate well with the findings of Wang [23], who reported that SBT positively affected the body weight of laying hens. It has also been reported that supplementation of SBT leaves extract, pulp, and oil significantly $(\mathrm{p}<0.05)$ increased the body weight gain [24].

\section{FCR}

The results of the present study are in accordance with the findings of Pathak et al. [24] and Kaushal and Sharma [25]. It has been observed that supplementation of SBT leaves extract, pulp, and oil leads to better FCR compared to control group [24]. Further, the addition of SBT cake in poultry feed up to $30 \%$ replacement of crude protein showed better growth response and FCR [25]. In addition, FCR with diets having 5\% SBT fruit residue meal was higher than control group [26].

\section{Blood biochemical parameters}

In our study, plasma uric acid was significantly increased $(p<0.05)$ in control group than giloe and group having supplementation of both SBT and giloe leaf meal. Further, plasma ALP value was significantly higher $(\mathrm{p}<0.05)$ in control than SBT supplemented group. In addition, plasma uric acid, cholesterol, aspartate aminotransferase (AST), alanine aminotransferase (ALT) and ALP, and serum LPO values were comparatively higher in the control group than other treatment groups. Ahera and Wahib [27] noted that that ethanolic extract of $T$. cordifolia increased the level of liver mitochondrial enzymes such as glutathione, catalase, and SOD but decreased the level of LPO in the liver. Therefore, it was evident that T. cordifolia has antioxidant activity as well as immune-modulator property through protecting the cells from the oxidative damage. Stanely et al. [28] reported that administration of the extract of $T$. cordifolia roots $(2.5$

Table-5: Effect of sea buckthorn and giloe leaf meal supplementation on blood biochemical parameters (protein, cholesterol, uric acid, alkaline phosphatase, SGOT, and SGPT) of turkey poults after 8 weeks of age.

\begin{tabular}{lcccccc}
\hline Treatment & Protein $(\mathbf{g} / \mathbf{d L})$ & Uric acid $(\mathbf{m g} / \mathbf{d L})$ & Cholesterol $(\mathbf{m g} / \mathbf{d L})$ & AST (IU/L) & ALT (IU/L) & ALP (IU/L) \\
\hline T1 & 3.88 & $7.99^{\mathrm{b}}$ & 128.99 & 4.53 & 5.97 & $188.82^{\mathrm{b}}$ \\
T2 & 3.84 & $6.65^{\mathrm{ab}}$ & 118.03 & 4.42 & 5.08 & $164.42^{\mathrm{a}}$ \\
T3 & 4.26 & $5.84^{\mathrm{a}}$ & 122.01 & 3.98 & 5.53 & $182.38^{\mathrm{b}}$ \\
T4 & 4.34 & $6.11^{\mathrm{a}}$ & 121.12 & 3.43 & 4.42 & $177.98^{\mathrm{ab}}$ \\
Pooled SEM & 0.09 & 0.29 & 1.75 & 0.20 & 0.33 & 3.16 \\
Sig level & $\mathrm{NS}$ & $\mathrm{p}<0.05$ & $\mathrm{NS}$ & $\mathrm{NS}$ & $\mathrm{NS}$ & $\mathrm{p}<0.05$ \\
\hline
\end{tabular}

Means bearing different superscripts within a column differ significantly $(p<0.05)$. NS=Non-significant $(p>0.05)$ $\mathrm{SEM}=$ Standard error of means. AST=Aspartate aminotransferase, ALT=Alanine aminotransferase, ALP=Alkaline phosphatase, SGOT=Serum glutamate oxaloacetate transaminase, SGPT=Serum glutamate pyruvate transaminase 
Table-6: Effect of sea buckthorn and giloe leaf meal supplementation on blood biochemical parameters (HDL, SOD, and LPO) of turkey poults after 8 weeks of age.

\begin{tabular}{lccc}
\hline Treatment & HDL $\mathbf{( m g / d L )}$ & SOD (units $/ \mathbf{m L})$ & LPO $(\mathbf{n M} / \mathbf{m L})$ \\
\hline T1 & 60.61 & 457.87 & 0.19 \\
T2 & 62.35 & 331.49 & 0.04 \\
T3 & 64.49 & 376.89 & 0.04 \\
T4 & 63.19 & 345.60 & 0.05 \\
Pooled SEM & 0.72 & 21.90 & 0.03 \\
Sig level & NS & NS & NS \\
\hline
\end{tabular}

NS=Non-significant $(p>0.05)$, SEM=Standard error of means, HDL=High-density lipoprotein, SOD=Superoxide dismutase, LPO=Lipid peroxidation

and $50 \mathrm{mg} / \mathrm{kg}$ body weight) for 6 weeks resulted in a significant reduction of serum and tissue cholesterol, phospholipids, and free fatty acids in alloxan diabetic rats. Kavitha et al. [29] reported that ethanolic extract of all the parts of giloe showed significant hepatoprotective effect by a reduction in serum enzymes ALT, AST, ALP, and total bilirubin in rats.

\section{Proximate analysis of breast (pectoralis major) mus- cles and thigh (ilio tibialis) muscles}

The higher zinc level in SBT and both SBT and giloe supplemented groups in breast as compared to control in our study may be due to a higher level of zinc in SBT leaves $(2.83 \mathrm{mg} / 100 \mathrm{~g})$. Further, the SBT leaves also had a higher EE percent $(6.93 \%)$ which was reflected in the higher level of EE percent in the thigh of the SBT leaf meal supplemented group. The findings of our study fall in line with Mahmoud et al. [26] who reported that percentage of breast muscles and thigh muscles in live weight was not significantly different between the groups of birds with $5 \%$ SBT fruit residues. However, Li et al. [30] concluded that crude protein of thigh muscle was significantly increased, and EE of thigh muscle was significantly decreased by the diet supplemented with $0.1 \%$ and $0.2 \%$ flavones of SBT in broilers.

\section{Conclusion}

The findings of the present study revealed that supplementation of SBT leaf meal at $0.5 \%$ may improve production performance of turkey poults. There was no adverse effect on the blood biochemical attributes of turkey poults subjected to SBT and giloe leaf meal supplementation at $0.5 \%$. Supplementation of $0.5 \%$ SBT leaf meal may result in higher levels of zinc and EE in the breast and thigh cuts of turkey poults.

\section{Authors' Contributions}

AS conducted the experimental work and UK assisted during the experiment. $\mathrm{AB}, \mathrm{BY}$, and $\mathrm{AP}$ wrote the article and corrected it. PKS, AB, and DR designed the study. All authors read and approved the final manuscript.

\section{Acknowledgments}

The authors are grateful to Vice Chancellor, DUVASU, Mathura, for providing the necessary facilities and funds for carrying out this study (University Grant to Department of Poultry Science, Dated 12/05/16, Financial Year 2016-17).

\section{Competing Interests}

The authors declare that they have no competing interests.

\section{References}

1. Dhanze, H., Khurana, S.K. and Mane, B.G. (2013) Effect of seabuckthorn leaf extract on microbiological quality of raw chicken during extended periods of storage. J. Food Quality, 36: 59-65.

2. Biswas, A., Bharti, V.K., Acharya, S., Pawar, D.D. and Singh, S.B. (2010) Sea buckthorn: New feed opportunity for poultry in cold arid Ladakh region of India. World's Poult. Sci. J., 66(4): 707-714.

3. Geetha, S., Jayamurthy, P., Pal, K., Pandey, S. and Sawhney, R.C. (2008) Hepatoprotective activity of sea buckthorn (Hippophae rhamnoides L.) L against carbon tetrachloride induced hepatic damage in rats. J. Sci. Food Agric., 88: 1592-1597.

4. Guan, T.T.Y., Cenkowski, S. and Hydamaka, A. (2005) Effect of drying on the nutraceutical quality of Sea buckthorn (Hippophae rhamnoides L. ssp. Sinensis) leaves. $J$. Food Sci., 70: 514-518.

5. Kashif, M. and Ullah, S. (2013) Chemical composition and minerals analysis of Hippophae rhamnoides, Azadirachta indica, Punica granatu and Ocimum sanctum leaves. World J. Dairy Food Sci., 8(1): 67-73.

6. Kumar, R., Kumar, G.P., Chaurasia, O.P. and Singh, S.B. (2011) Phytochemical and pharmacological profile of Sea buckthorn oil: A review. Res. J. Med. Plant, 5: 491-499.

7. Khosa, R.L. and Prasad, S. (1971) Pharmacognostical studies on Guduchi (Tinospora cordifolia Miers). J. Res. Ind. Med., 6: 261-269.

8. Zhao, T.F., Wang, X., Rimando, A.M. and Che, C. (1991) Folkloric medicinal plants: Tinospora sagittata var. Cravaniana and Mahonia bealei. Planta. Med., 57: 505.

9. Hussain, J., Khan, A.L., Rehman, N., Hamayun, M., Shinwari, Z.K., Ullah, W. and Lee, I.J. (2009) Assessment of herbal products and their composite medicinal plants through proximate and micronutrients analyses. J. Med. Plant Res., 3: 1072-1077.

10. Pandey, M., Paul, V., Singh, P. and Ali, Z. (2016) Evaluation of nutritional composition and antioxidant activity of herbal leaves. World J. Pharm. Pharm. Sci., 5(8): 1396-1402.

11. Hu, J.Z. (2000) Eco-Economic Values and Comprehensive Development Techniques of Sea Buckthorn. The Yellow River Water Conservancy Press, Zhengzhou.

12. Hu, J.Z. and Guo, X.F. (2006) Evaluation of nutrient value of Sea buckthorn in north China. Forestry Stud. China, 8: $50-52$

13. Chen, X., Zhao, W., Liu, H.N., Su, J., Zhang, Z.H. and Li, Y. (2011) Effect of Sea buckthorn leaves on growth performance and calcium metabolism in Arbor Acres broilers. 
Dongbei Nongye Daxue Xue Bao, 42: 19-24.

14. Kulkarni, R.C., Mandal, A.B., Munj, C.P., Dan, A., Saxena, A. and Tyagi, P.K. (2011) Response of coloured broilers to dietary addition of Geloi (Tinospora cordifolia) during extreme summer. Indian J. Poult. Sci., 46(1): 70-74.

15. Singh, A., Kaushik, P.K., Yadav, P.K. and Yadav, P. (2014) Effect of Bael (Aegle marmelos) and Giloy (Tinospora cordifolia) alone and in combination on growth and feed conversion of broiler chicks. Global J. Res. Anal., 3: 96-99.

16. AOAC. (2005) Official Methods of Analysis. $18^{\text {th }}$ ed. Association of Official Analytical Chemists, Washington, DC.

17. Ohkawa, H., Ohishi, N. and Yagi, K. (1979) Assay of lipid peroxides in animal tissues by thiobarbituric acid reaction. Anal. Biochem., 95: 351-358.

18. Madesh, M. and Balasubramanian, K.A. (1998) Microtiter plate assay for superoxide dismutase using MTT reduction by superoxide. Indian J. Biochem. Biol., 35(3): 184.

19. Kolmer, J.A., Spandling, E.H. and Robinson, H.W. (1951) Approved Laboratory Technique. $5^{\text {th }}$ ed. Appleton Century Crofts Inc., New York.

20. Snedecor, G.W. and Cochran, W.G. (1994) Statistical Methods. $9^{\text {th }}$ ed. The Iowa, State University Press, Ames, Iowa.

21. SPSS. (2011) Statistics Version 20.0. IBM SPSS Inc., USA.

22. Duncan, D.B. (1955) Multiple range and multiple F tests. Biometrics, 11: 1-42.

23. Wang, Y.C. (1997) Analysis on nutrition elements of Sea buckthorn. Hippophae, 10: 24-25.
24. Pathak, G.P., Sharma, N., Mane, B.G., Sharma, D., Krofa, D. and Khurana, S.K. (2015) Effect of Sea buckthorn (Hippophae rhamnoides)-leaves, pulp and oil on growth performance, carcass characteristics and meat quality of broilers chicken. J. Poult. Sci. Technol., 3(1): 20-23.

25. Kaushal, M. and Sharma, P.C. (2011). Nutritional and antimicrobial property of Sea buckthorn seed oil. J. Sci. Ind. Res., 70: 1033-1036.

26. Mahmoud, Z.B., Mohamed, M.S., Blaha, J., Lukesova, D. and Kunc, P. (2014) The effect of Sea buckthorn (Hippophae rhamnoides L.) residues in compound feeds on the performance and skin color of broilers. Indian J. Anim. Res., 48: 548-555.

27. Ahera, V. and Wahib, A.K. (2012) Biotechnological approach to evaluate the immunomodulatory activity of ethanolic extract of Tinospora cordifolia stem (mango plant climber). Iran. J. Pharm. Res., 11(3): 863-872.

28. Stanely, M., Prince, P., Menon, V.P. and Gunasekaran, G. (1999) Hypolipidaemic action of Tinospora cordifolia roots in alloxan diabetic rats. J. Ethnopharmacol., 64(1): 53-57.

29. Kavitha, B.T., Shruthi, S.D., Rai, S.P. and Ramachandra, Y.L. (2011) Phytochemical analysis and hepatoprotective properties of Tinospora cordifolia against carbon tetrachloride-induced hepatic damage in rats. J. Basic. Clin. Pharm., 2(3): 139-142.

30. Li, Y., Fu, J., Wang, B., Wang, Y. and Shan, A. (2008) Effect of flavones of sea buckthorn on carcass characteristics and meat quality of Arbor Acres broilers. Chinese J. Anim. Vet. Sci., 39(9): 1217-1223. 